\title{
Field and Storage Evaluations of 'SpuntaG2' for Resistance to Potato Tuber Moth and Agronomic Performance
}

\author{
David Douches ${ }^{1}$ \\ Department of Crop and Soil Sciences, A499B Plant and Soil Science Building, Michigan State \\ University, East Lansing, MI 48824
}

\begin{abstract}
Walter Pett
Department of Entomology, 444 Natural Science Building, Michigan State University, East Lansing, MI 48824
\end{abstract}

Diedrich Visser

Agricultural Research Council, Vegetable and Ornamental Plant Institute, Private Bag X293, Pretoria 0001 South Africa

Joseph Coombs, Kelly Zarka, and Kimberly Felcher

Department of Crop and Soil Sciences, A499B Plant and Soil Science Building, Michigan State University, East Lansing, MI 48824

Gurling Bothma

Agricultural Research Council, Vegetable and Ornamental Plant Institute, Private Bag X293, Pretoria 0001 South Africa

Johan Brink

Institute of International Agriculture, 319 Agriculture Hall, Michigan State University, East Lansing, MI 48824

Muffy Koch

Independent consultant, 4502 Donnelly Drive, RR\#4, Merrickville, ON, Canada K0G 1NO

Hector Quemada

Institute of International Agriculture, 319 Agriculture Hall, Michigan State University, East Lansing, MI 48824; and Donald Danforth Plant Science Center, St. Louis, MO 63132

\begin{abstract}
AdDitional Index words. South Africa, quality, Bacillus thuringiensis, Phthorimaea operculella, transgenic, crylla1 gene, deregulation

Abstract. 'SpuntaG2' is a transgenic potato (Solanum tuberosum) cultivar that contains the crylIal gene for resistance to potato tuber moth (Phthorimaea operculella), which is a serious pest of potato in many parts of the world. Previous studies have characterized 'SpuntaG2' at the molecular level and evaluated it for safety as a human food source. The objective here was to determine the efficacy of 'SpuntaG2' against the potato tuber moth in the field and in storage and to evaluate its agronomic performance. Efficacy trials at seven South African locations over 5 years indicated that 'SpuntaG2' gave complete control of potato tuber moth in the field and storage. The agronomic performance (tuber size and yield) of 'SpuntaG2' was not statistically different from 'Spunta' or was better than 'Spunta' at all locations/years with two exceptions. Three years of trials in Michigan further support these conclusions. Evaluations done during the 2006-07 South African season showed that 'SpuntaG2' did not differ from non-transgenic 'Spunta' for the following traits: maturity, growth habit, eye morphology, tuber size distribution, tuber shape, skin and flesh color, growth cracks, internal defects, specific gravity, chip color, cooking quality, disease resistance, and pollen fertility. Based on the results of these trials, it was concluded that 'SpuntaG2' provides the agronomic performance of 'Spunta' with the added benefit of resistance to potato tuber moth.
\end{abstract}

Potato tuber moth is a serious pest of potato in South Africa. This insect causes damage during the growing season and in potato storage. The life cycle of potato tuber moth can be completed within 20 to $30 \mathrm{~d}$ and there may be as many as 12 generations in a single year (Raman, 1980). Adult tuber moths

Received for publication 19 Jan. 2010. Accepted for publication 2 Apr. 2010. ${ }^{1}$ Corresponding author. E-mail: douchesd@msu.edu. live for 10 to $15 \mathrm{~d}$ and during this time the females lay clusters of eggs on potato plants (leaves, stems, and tubers), storage containers (sacks, boxes, etc.), and dirt or debris surrounding tubers (Raman, 1980). Larvae typically emerge from the eggs after $5 \mathrm{~d}$ of incubation (Goldson and Emberson, 1985) and begin feeding on leaves, stems, and tubers. Larval mining on the plant results in the loss of leaf tissue, death of growing points, and weakening or breakage of stems (Raman, 1980), all 
of which can reduce yield. Tuber mining results in tubers that are not marketable or consumable and renders tubers susceptible to infection by potato pathogens (Alvarez et al., 2005). After $\approx 8 \mathrm{~d}$ of feeding, the larvae pupate and emerge as adults after 6 to 9 d (Alvarez et al., 2005).

Host plant resistance to potato tuber moth is highly desirable, and components of resistance such as glandular trichomes and acetylated glycoalkaloids (leptines) have been identified in wild potato species such as Solanum berthaultii, Solanum polyadenium, Solanum tarijense, and Solanum chacoense. However, attempts to introduce these resistance components into cultivated potato have been difficult due to linkage with undesirable traits (Kalazich and Plaisted, 1991). Currently, traditional breeding has not produced a commercial potato cultivar that is resistant to potato tuber moth (Lagnaoui et al., 2000). Therefore, commercial producers rely on insecticide application for tuber moth control in the field, and subsistence level farmers that cannot afford insecticides have no recourse. Aldicarb (a carbamate) is applied at planting and organophosphates or pyrethroids are generally applied at weekly intervals starting when the first potato tuber moths appear or when specific tuber moth thresholds are reached. Insecticides are applied from eight to twelve times per season, with the number of applications depending on the season of the year as well as on the level and progression of the infestation. Tuber moth infestation is typically lower and slower to progress during the winter season thus fewer applications are necessary. However, control is not always satisfactory and damage levels vary between seasons and years, depending largely on the survival of overwintering moths and their reinfestation of newly planted fields (Visser, 2004). Adult tuber moths can migrate from infested fields to cull piles and storages to lay eggs. Tuber moth eggs are destroyed by low temperature $\left(1.7-4.4^{\circ} \mathrm{C}\right)$ exposure for 4 months, while all other life stages are destroyed by temperatures in excess of $36{ }^{\circ} \mathrm{C}$ for $15 \mathrm{~d}$ (Trivedi and Rajagopal, 1992). Therefore, in cull piles and storage, where temperatures are often ideal and no insecticides are applied, all life-stages of tuber moths are likely to survive the winter and to infest potato fields the following season (Alvarez et al., 2005).

Potato tuber moth not only attacks tubers in the soil, but also in storage. Unfortunately, there are no insecticides registered for use in South Africa to control potato tuber moth under storage conditions, including Bt sprays (Nel et al., 2002). The only control strategy that gives consistently good control against the potato tuber moth is the use of genetically modified, insectresistant potatoes containing the cryllal gene (Visser, 2004).

'SpuntaG2' is a transgenic potato cultivar containing the cryllal gene from Bacillus thuringiensis for resistance to potato tuber moth. This cultivar has been characterized at the molecular level (Zarka et al., 2010) and has been thoroughly evaluated for safety as a human food source (Quemada et al., 2010). The current study focuses on the agronomic performance of 'SpuntaG2' and its efficacy against potato tuber moth in the field and in storage.

\section{Materials and Methods}

Field TRIAL DESIGN. Five years of field trials were conducted at seven South African sites to evaluate 'SpuntaG2' for resistance to potato tuber moth and for agronomic performance. The sites were chosen to represent the various growing regions in South Africa and included Ceres, Dendron, Roodeplaat, Kokstad (irrigated), Kokstad (dry land), Patensie, and Petrus
Steyn. All field trials were randomized block designs with four replicates and are summarized in Table 1. 'Spunta', 'Mnandi', and 'BP1' were used as control cultivars. 'Mnandi' is favored by small-scale farmers and has potato late blight (Phytophthora infestans) resistance. The cultivar BP1 is the top commercial cultivar in South Africa and 'Spunta' is the non-transgenic cultivar from which 'SpuntaG2' was derived. Each year greenhouse-grown, virus- and disease-free mini-tubers were planted. The only exception was the 2005-06 season during which tubers harvested from the previous year's trials were used for planting. Plots consisted of three rows of test material bordered on each side by non-transgenic controls. Rows were $3 \mathrm{~m}$ in length with $1 \mathrm{~m}$ spacing between rows and 10 seed pieces were planted per row. However, during the 2005-06 and 2006-07 seasons, plot sizes were altered at Petrus Steyn, Dendron, and Roodeplaat to accommodate the practices and equipment of the farm operation. At the Dendron site, the plot rows were $5 \mathrm{~m}$ in length with $0.8 \mathrm{~m}$ spacing between rows and 16 seed pieces planted per row. The Roodeplaat 2005-06 site was planted in rows that were $11 \mathrm{~m}$ long with $1.34 \mathrm{~m}$ row spacing and 36 plants per row. At the Petrus Steyn site, rows were $9 \mathrm{~m}$ long with $1.65 \mathrm{~m}$ spacing between rows and 36 tubers were planted per row. Supplemental irrigation was applied as needed with the exception of the Kokstad dry land site and the Petrus Steyn site. At all sites, natural infestations of potato tuber moths were used with the exception of the 2002-03 Roodeplaat site where $\approx 30,000$ tuber moths were released over the course of the growing season.

Fields were inspected regularly for tuber moth infestations by scouting the non-transgenic control plots to look for the presence of leaf mines. When more than $15 \%$ of the plants in the control plots were attacked, the rest of the plots were scouted as well. During scouting, the following data were recorded from 25 randomly selected haulms per plot: the number of haulms attacked, the number of leaf mines present, and the number of live larvae.

Two weeks before harvest, all haulms were destroyed by herbicide application (paraquat) or by slashing or pulling the haulms. At harvest, all tubers from each plot were kept separate in clearly marked containers. Weighing and sorting were done on sorting tables in the potato stores at the South African Agricultural Research Council's (ARC) facilities in Roodeplaat, and by hand in the field at all other locations. Tubers from all plots were weighed separately after sorting into standard categories: large $(>200 \mathrm{~g})$, medium $(>80$ and $<200 \mathrm{~g})$, small $(<80 \mathrm{~g})$, and unmarketable (small enough to fall through the sorter or rotten/damaged). While sorting, all tubers with any sign of tuber moth damage were sorted out into the nonmarketable group. These nonmarketable tubers were inspected later and all tubers with potato tuber moth damage were weighed. All tubers were stored in temperature-controlled cooling facilities. All rotten or discarded tubers were killed by freezing or burning and were then buried in 2- to 3-m-deep holes. During the 2005-06 and 2006-07 seasons in Roodeplaat, 'Spunta' and 'SpuntaG2' plots were evaluated for several agronomic properties by A. Visser. These properties included maturity, growth habit, foliage cover, mature plant height, tuber size distribution, tuber dimensions/shape, skin color, eye morphology, growth cracks, skin cracking/mechanical damage, flesh color, internal qualities, specific gravity, chip scores, cooking quality, and response to Fusarium dry rot (Fusarium spp.), stem-end rot (Fusarium spp.), common scab (Streptomyces scabies), potato late blight, potato early blight (Alternaria solani), and root knot nematode (Meloidogyne spp.). All traits 
Table 1. Summary of South African field trials to test the efficacy of potato cultivar SpuntaG2 (containing the crylIal gene) against potato tuber moth.

\begin{tabular}{|c|c|c|c|}
\hline Location & Cultivars $^{\mathrm{z}}$ & Irrigation practices & Outcome of trialy \\
\hline \multicolumn{4}{|l|}{$2006-07$} \\
\hline Roodeplaat & SpuntaG2, Spunta & Irrigated & Agronomic data only \\
\hline Ceres & SpuntaG2, Spunta & Irrigated & Agronomic data only \\
\hline \multicolumn{4}{|l|}{$2005-06$} \\
\hline Roodeplaat & SpuntaG2, Spunta & Irrigated & Data on tuber moth damage collected \\
\hline Petrus Steyn & SpuntaG2, Spunta & Dry land & No tuber moth data collected \\
\hline Patensie & SpuntaG2, Spunta & Irrigated & Data on tuber moth damage collected \\
\hline Kokstad & SpuntaG2, Spunta & Irrigated & Data on tuber moth damage collected \\
\hline Kokstad & SpuntaG2, Spunta, BP1 & Dry land & Data on tuber moth damage collected \\
\hline Dendron & SpuntaG2, Spunta & Irrigated & Only tuber damage data collected \\
\hline Patensie & SpuntaG2, Spunta, BP1 & Irrigated & Data on tuber moth damage collected \\
\hline Kokstad & SpuntaG2, Spunta, BP1 & Irrigated & Data on tuber moth damage collected \\
\hline Kokstad & SpuntaG2, Spunta, BP1 & Dry land & Data on tuber moth damage collected \\
\hline Dendron & SpuntaG2, Spunta, BP1 & Irrigated & No tuber moth data collected \\
\hline \multicolumn{4}{|l|}{ 2003-04 } \\
\hline Roodeplaat & SpuntaG2, Spunta, BP1 & Irrigated & Data on tuber moth damage collected \\
\hline Ceres & SpuntaG2, Spunta, BP1 & Irrigated & Data on tuber moth damage collected \\
\hline Kokstad & SpuntaG2, Spunta, Mnandi & Irrigated & Storage trial only \\
\hline \multicolumn{4}{|l|}{$2002-03$} \\
\hline
\end{tabular}

'Spunta', 'BP1', and 'Mnandi' = non-transgenic control cultivars.

${ }^{y}$ No tuber moth damage was collected if tuber moth infestation was too low or if the trial had to be ended early due to fields infected with virus.

were evaluated in accordance with the protocols established by the International Union for the Protection of New Varieties of Plants (UPOV, 1986). In addition, 64 pollen samples from both cultivars were tested for fertility with the lacto phenol-acid fuchsin pollen fertility staining technique (Alexander, 1980) and with pollen germination on artificial media (Mortenson et al., 1964).

Statistics were conducted using analysis of variance (ANOVA) and Fisher's protected least significant difference (LSD) for means separation $(\alpha=0.05)$. All ANOVA were performed using the SAS (release 8.20; SAS Institute, Cary, NC) general linear model procedure at $\alpha=0.05$.

Agronomic evaluations of 'SpuntaG2' were also conducted in Michigan during the 2000, 2001, and 2002 seasons. The field experiments were planted in a randomized complete block design with four replications at the Montcalm Research Farm, Entrican, MI. The plots were $7 \mathrm{~m}$ long with $0.3 \mathrm{~m}$ spacing between plants and an interrow spacing of $0.86 \mathrm{~m}$. Supplemental irrigation was applied as needed. In each of the trials, the yield was graded into four size classes: $\mathrm{A}=113$ to $285 \mathrm{~g}, \mathrm{~B}=<113 \mathrm{~g}$, oversize $=>285 \mathrm{~g}$, and pickouts $=$ unmarketable. Tubers $>8.3 \mathrm{~cm}$ in diameter or $>285 \mathrm{~g}$ in weight were scored for incidence of external and internal defects, and samples of A-sized tubers were taken to determine specific gravity. Statistics for the replicated field trials were conducted using ANOVA and LSD for means separation $(\alpha=0.05)$. All ANOVA were performed using the SAS (release 8.20) general linear model procedure at $\alpha=0.05$.

STORAGE TRIals. After the completion of the field trials in 2002-03, 2003-04, and 2004-05, diffused light storage trials were started, using undamaged tubers harvested from the field. Three different storage facilities were used to simulate the types of storage set-ups used by small-scale and commercial growers in South Africa: a rustic out-building (Roodeplaat), an out-building in good condition with one window (Kokstad), and a commercial storage facility (Ceres). Tubers were stored for 6 months under diffused light storage conditions to evaluate the efficacy of the cryllal gene under long-term storage. Ten tubers of each treatment were stored in mini-crates stacked in a randomized block design. Four replicates were used (one replicate per stack or rack). In addition to natural infestations, 20 to 40 tuber moths were released into all the crates at 2- to 3-week intervals during the first 2 months of the storage experiment. Tuber moths for these experiments were collected from the farms and were reared on potato tubers until released into the storage crates.

\section{Results}

2002-03 EFFICACY AND STORAGE TRIALS. Of the two trials conducted during this growing season, only the Ceres trial had 
good natural infestations of potato tuber moth. Despite the high level of infestation, 'SpuntaG2' plots showed complete resistance to potato tuber moth (Table 2). In the same trial, 'Spunta' and 'BP1' control plots had an average of $98 \%$ and $87.2 \%$ tuber moth-damaged haulms per plot, respectively.
One storage trial was conducted at the Roodeplaat site following the 2002-03 season. The transgenic cultivar SpuntaG2 showed complete protection against potato tuber moth infestation for the duration of the storage trial ( $237 \mathrm{~d}$ postharvest) (Table 3). In contrast, the control cultivars were severely

Table 2. Results from South African field trials of potato cultivars SpuntaG2 (transgenic), Spunta (non-transgenic), and BP1 (non-trangenic) for efficacy against potato tuber moth foliar mining.

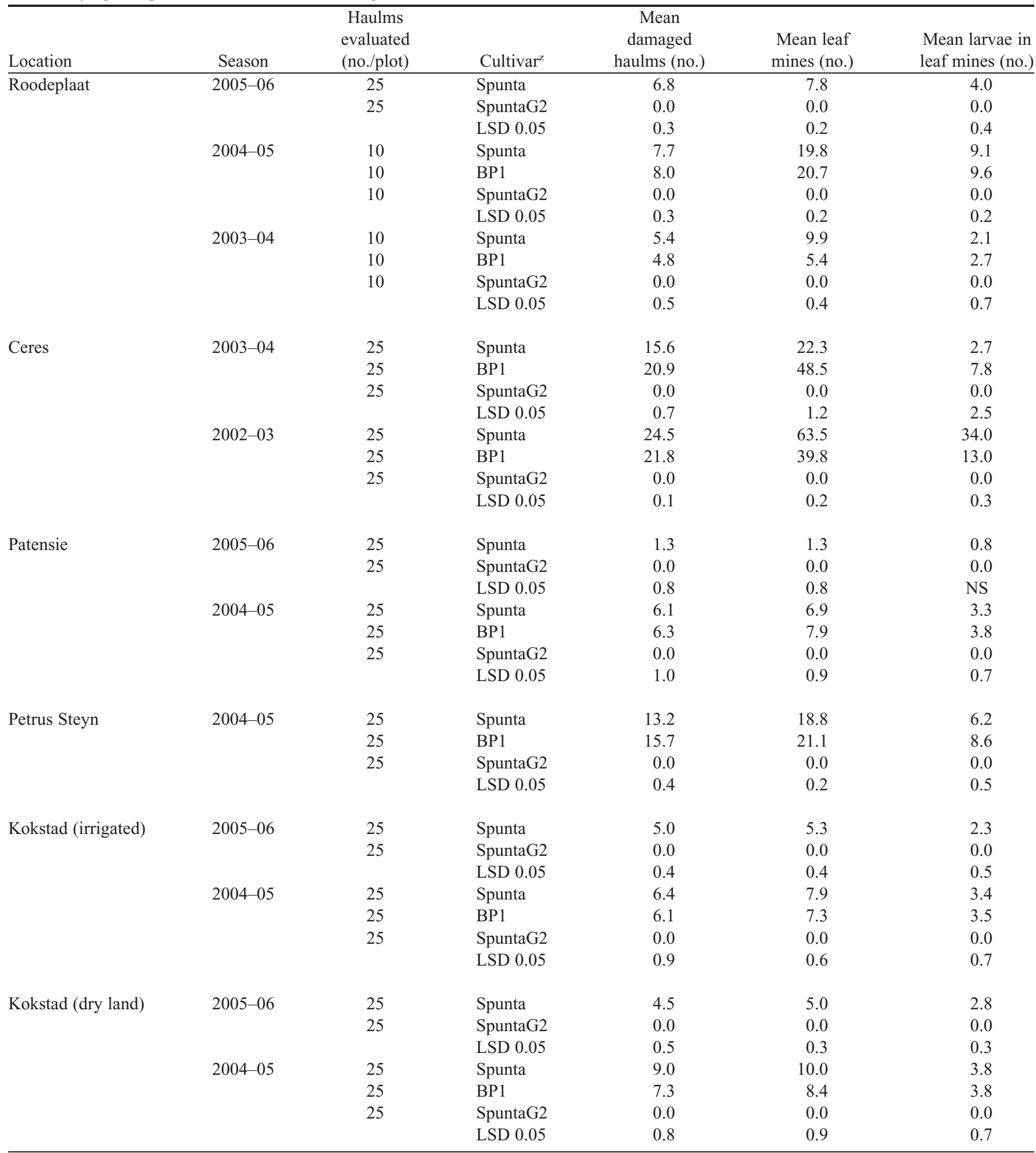

z'Spunta' and 'BP1' are control cultivars; 'SpuntaG2' contains the cryllal gene for potato tuber moth resistance. 
Table 3. Comparison of potato cultivar SpuntaG2 (transgenic) to non-transgenic control cultivars (Spunta, Mnandi, and BP1) for the average number of tubers infested with potato tuber moth in 3 years of South African storage trials.

\begin{tabular}{|c|c|c|c|c|c|}
\hline $\begin{array}{l}\text { Growing } \\
\text { season }\end{array}$ & $\begin{array}{c}\text { Storage } \\
\text { location } \\
\end{array}$ & $\begin{array}{c}\text { Type of storage } \\
\text { facility } \\
\end{array}$ & Cultivar $^{2}$ & $\begin{array}{l}\text { Tubers evaluated } \\
\text { (no./replication) }\end{array}$ & $\begin{array}{c}\text { Mean infested } \\
\text { tubers (no.) }\end{array}$ \\
\hline \multirow[t]{2}{*}{$2002-03$} & Roodeplaat & Rustic out-building & Spunta & 10 & 10 \\
\hline & & & BP1 & 10 & 10 \\
\hline \multirow[t]{8}{*}{$2003-04$} & Ceres & Commercial storage & Spunta & 50 & 5.5 \\
\hline & & & BP1 & 50 & 8.3 \\
\hline & & & SpuntaG2 & 50 & 0.0 \\
\hline & & & BP1 & 20 & 19.3 \\
\hline & & & SpuntaG2 & 20 & 0.0 \\
\hline & Roodeplaat & Rustic out-building & Spunta & 20 & 20.0 \\
\hline & & & $\mathrm{BP} 1$ & 20 & 20.0 \\
\hline & & & SpuntaG2 & 20 & 0.0 \\
\hline
\end{tabular}

'Spunta', 'Mnandi', and 'BP1' are non-transgenic controls; 'SpuntaG2' contains the crylIal gene.

y'rial was destroyed by monkeys.

infested and damaged. In fact, new tubers of 'BP1' had to be added to storage at $200 \mathrm{~d}$ postharvest as the initial tubers had been completely destroyed by tuber moths.

2003-04 EFFICACY AND STORAGE TRIALS. Infestation in November was low, but increased during the December evaluations at the Roodeplaat site. Despite moderate infestation rates in the non-transgenic controls (an average of 54\% damaged haulms per plot for 'Spunta'), 'SpuntaG2' showed no signs of foliar tuber moth infestation (Table 2). At the Ceres site, natural infestations of tuber moth were high throughout the trial. 'SpuntaG2' gave absolute tuber moth control, while the control cultivars Spunta and BP1 had an average of $62.4 \%$ and $83.6 \%$ damaged haulms per plot, respectively (Table 2 ).

Three storage trials were conducted following the 2003-04 growing season (Ceres, Kokstad, and Roodeplaat). In all three trials, 'SpuntaG2' tubers showed no potato tuber moth damage in contrast to the control cultivars (Spunta and BP1), which were moderately to heavily infested. The mean percentage of damaged tubers for 'Spunta' was 95\% at Kokstad, 100\% at Roodeplaat, and $11 \%$ at Ceres (Table 3). 'BP1' gave results similar to those of 'Spunta' at all three sites.
2004-05 EFFICACY AND STORAGE TRIALS. The autumn (or early winter) planting at Roodeplaat showed an unexpectedly good potato tuber moth infestation. Ten haulms per plot were examined in this trial. In the 'Spunta' control, the mean percentage of tuber moth-damaged haulms was $77 \%$ as opposed to no damaged haulms in the 'SpuntaG2' plots (Table 2). Efficacy trials at Kokstad (dry land and irrigated), Patensie, and Petrus Steyn gave similar results (Table 2). A storage trial was initiated following the 2004-05 season at Roodeplaat. All of the non-transgenic controls were infested during storage, whereas 'SpuntaG2' was not infested (Table 3).

2005-06 EFFICACY TRIALS. The summer trial at Roodeplaat had mild tuber moth infestations in the 'Spunta' control plots (an average of $27.2 \%$ damaged haulms per plot) and no infestations in the 'SpuntaG2' plots (Table 2). In Kokstad, there were low levels of tuber moth infestation in the control plots, with no differences between the dryland and irrigated trials (an average of $20 \%$ and $18 \%$ damaged haulms per plot, respectively). 'SpuntaG2' plots had no evidence of tuber moth infestation (Table 2). The Patensie trial had very low levels of tuber moth infestation due in part to the application

Table 4. Results of 3 years of field trials to evaluate the yield, size distribution, specific gravity, and tuber quality of potato cultivars SpuntaG2 (transgenic) and Spunta (non-transgenic) conducted at the Michigan State University, Montcalm Research Farm in Entrican, MI.

\begin{tabular}{|c|c|c|c|c|c|c|c|c|c|c|c|c|c|c|}
\hline \multirow[b]{2}{*}{ Year } & \multirow[b]{2}{*}{ Cultivar } & \multicolumn{2}{|c|}{ Yield $\left(\mathrm{Mg} \cdot \mathrm{ha}^{-1}\right)$} & \multicolumn{5}{|c|}{ Size categories $(\% \text { of total })^{y}$} & \multirow[b]{2}{*}{ Specific gravity } & \multicolumn{5}{|c|}{ Tuber quality ( $\%$ of total cut $)^{\mathrm{x}}$} \\
\hline & & $\mathrm{US} \# 1^{\mathrm{z}}$ & Total & US\#1 & $\mathrm{B}$ & A & $\mathrm{OV}$ & $\mathrm{PO}$ & & $\mathrm{HH}$ & VD & IBS & $\mathrm{BC}$ & Total cut \\
\hline 2000 & SpuntaG2 & 60.6 & 70.3 & 86 & 11 & 61 & 25 & 3 & 1.063 & 0 & 0 & 0 & 0 & 40 \\
\hline \multirow[t]{3}{*}{2001} & Spunta & 44.1 & 56.0 & 79 & 14 & 61 & 17 & 7 & 1.058 & 0.13 & 2.5 & 2.5 & 2.5 & 40 \\
\hline & SpuntaG2 & 47.3 & 59.0 & 80 & 13 & 65 & 15 & 7 & 1.059 & 0 & 7.5 & 5.0 & 2.5 & 40 \\
\hline & $\mathrm{LSD}_{0.05}$ & NS & NS & & & & & & NS & & & & & \\
\hline & SpuntaG2 & 29.1 & 34.6 & 84 & 11 & 67 & 17 & 5 & 1.054 & - & - & - & - & 40 \\
\hline & $\mathrm{LSD}_{0.05}$ & NS & NS & & & & & & NS & & & & & \\
\hline
\end{tabular}

${ }^{\mathrm{z}} \mathrm{US} \# 1=$ tubers $>116 \mathrm{~g}$ in weight.

${ }^{\mathrm{y}} \mathrm{B}=<113 \mathrm{~g}, \mathrm{~A}=113$ to $285 \mathrm{~g}, \mathrm{OV}$ (oversize) $=>285 \mathrm{~g}, \mathrm{PO}=$ pickouts (tubers that are unmarketable).

${ }^{\mathrm{x}} \mathrm{HH}=$ hollow heart, $\mathrm{BC}=$ brown center, $\mathrm{VD}=$ vascular discoloration, IBS $=$ internal brown spot.

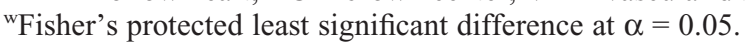


Table 5. Results of 5 years of field trials at seven South African locations to evaluate the yield and yield distribution of the potato cultivars SpuntaG2 (transgenic) and Spunta (non-transgenic).

\begin{tabular}{|c|c|c|c|c|c|c|c|c|}
\hline \multirow[b]{2}{*}{ Location } & \multirow[b]{2}{*}{$\mathrm{Yr}$} & \multirow[b]{2}{*}{ Cultivar } & \multicolumn{4}{|c|}{ Yield for each size category $(\mathrm{kg})^{\mathrm{z}}$} & \multirow[b]{2}{*}{ Total yield $(\mathrm{kg})$} & \multirow[b]{2}{*}{ Total yield $\left({\left.\mathrm{Mg} \cdot \mathrm{ha}^{-1}\right)}^{-1}\right.$} \\
\hline & & & $\mathrm{L}$ & $\mathrm{M}$ & $\mathrm{S}$ & $\mathrm{U}$ & & \\
\hline \multirow[t]{12}{*}{ Ceres } & $2002-03$ & Spunta & 87.9 & 14.2 & 4.3 & 2.6 & 109.0 & 93.1 \\
\hline & & SpuntaG2 & 92.3 & 14.1 & 5.3 & 1.4 & 112.3 & 96.0 \\
\hline & & $\operatorname{LSD}_{0.05^{\mathrm{y}}}$ & NS & NS & NS & NS & NS & NS \\
\hline & $2003-04$ & Spunta & 78.4 & 20.8 & 7.6 & 5.3 & 112.2 & 83.1 \\
\hline & & SpuntaG2 & 75.3 & 12.7 & 11.6 & 4.1 & 103.8 & 76.9 \\
\hline & & $\mathrm{LSD}_{0.05}$ & NS & $4.9^{x}$ & NS & NS & NS & NS \\
\hline & $2004-05$ & Spunta & 87.8 & 52.6 & 18.0 & 26.3 & 184.6 & 22.8 \\
\hline & & SpuntaG2 & 127.3 & 84.5 & 26.1 & 30.6 & 268.5 & 33.2 \\
\hline & & $\mathrm{LSD}_{0.05}$ & NS & NS & NS & NS & NS & NS \\
\hline & 2006-07 & Spunta & 186.2 & 134.0 & 52.7 & 85.5 & 458.3 & 56.6 \\
\hline & & SpuntaG2 & 147.8 & 157.6 & 72.9 & 53.0 & 431.3 & 53.2 \\
\hline & & $\mathrm{LSD}_{0.05}$ & NS & NS & NS & NS & NS & NS \\
\hline \multirow[t]{6}{*}{ Dendron } & $2004-05$ & Spunta & 1.5 & 5.7 & 5.7 & 4.2 & 17.3 & 14.4 \\
\hline & & SpuntaG2 & 2.2 & 6.6 & 5.6 & 5.5 & 19.2 & 16.6 \\
\hline & & $\mathrm{LSD}_{0.05}$ & NS & NS & NS & NS & NS & NS \\
\hline & 2005-06 & Spunta & 11.5 & 19.7 & 7.6 & 6.1 & 44.8 & 37.4 \\
\hline & & SpuntaG2 & 7.5 & 19.6 & 8.5 & 9.0 & 44.6 & 37.2 \\
\hline & & $\mathrm{LSD}_{0.05}$ & 2.9 & NS & NS & NS & NS & NS \\
\hline \multirow[t]{6}{*}{ Kokstad (irrigated) } & 2004-05 & Spunta & 46.4 & 26.5 & 4.2 & 9.5 & 87.1 & 58.0 \\
\hline & & SpuntaG2 & 49.9 & 25.0 & 5.6 & 8.9 & 89.3 & 59.5 \\
\hline & & $\mathrm{LSD}_{0.05}$ & NS & NS & NS & NS & NS & NS \\
\hline & 2005-06 & Spunta & 22.1 & 15.7 & 6.4 & 5.2 & 49.4 & 32.9 \\
\hline & & SpuntaG2 & 18.8 & 15.3 & 6.8 & 6.0 & 46.8 & 31.2 \\
\hline & & $\mathrm{LSD}_{0.05}$ & NS & NS & NS & NS & NS & NS \\
\hline \multirow[t]{3}{*}{ Kokstad (dry land) } & $2004-05$ & Spunta & 18.8 & 20.7 & 10.1 & 1.2 & 50.7 & 33.8 \\
\hline & & SpuntaG2 & 20.2 & 27.8 & 8.4 & 1.0 & 57.4 & 38.3 \\
\hline & & $\mathrm{LSD}_{0.05}$ & NS & 4.9 & NS & NS & NS & NS \\
\hline \multirow[t]{6}{*}{ Patensie } & $2004-05$ & Spunta & 36.7 & 14.3 & 7.1 & 5.5 & 66.0 & 44.0 \\
\hline & & SpuntaG2 & 31.9 & 12.5 & 9.8 & 7.1 & 61.3 & 40.9 \\
\hline & & $\mathrm{LSD}_{0.05}$ & NS & NS & 2.2 & NS & NS & NS \\
\hline & $2005-06$ & Spunta & 6.6 & 7.0 & 3.8 & 3.3 & 19.9 & 13.3 \\
\hline & & SpuntaG2 & 10.9 & 12.1 & 5.5 & 5.2 & 33.7 & 22.5 \\
\hline & & $\mathrm{LSD}_{0.05}$ & NS & NS & NS & NS & NS & NS \\
\hline \multirow[t]{9}{*}{ Petrus Steyn } & 2004-05 & Spunta & 118.6 & 63.0 & 29.0 & 10.2 & 228.1 & 25.6 \\
\hline & & SpuntaG2 & 114.1 & 60.2 & 37.9 & 13.8 & 226.0 & 25.4 \\
\hline & & $\mathrm{LSD}_{0.05}$ & NS & NS & NS & NS & NS & NS \\
\hline & $2005-06$ & Spunta & 26.0 & 26.9 & 32.5 & 6.9 & 92.3 & 10.4 \\
\hline & & SpuntaG2 & 18.5 & 31.8 & 47.4 & 4.5 & 102.1 & 11.5 \\
\hline & & $\mathrm{LSD}_{0.05}$ & NS & NS & NS & NS & NS & NS \\
\hline & 2006-07 & Spunta & 27.8 & 29.0 & 28.3 & 7.4 & 102.8 & 14.1 \\
\hline & & SpuntaG2 & 40.1 & 38.5 & 45.3 & 7.9 & 131.8 & 16.9 \\
\hline & & $\mathrm{LSD}_{0.05}$ & NS & NS & 10.9 & NS & NS & NS \\
\hline \multirow[t]{6}{*}{ Roodeplaat } & $2002-03$ & Spunta & 22.8 & 21.3 & 3.8 & 3.1 & 51.1 & - \\
\hline & & SpuntaG2 & 16.5 & 19.4 & 4.0 & 3.3 & 43.1 & - \\
\hline & & $\mathrm{LSD}_{0.05}$ & NS & NS & NS & NS & NS & - \\
\hline & 2003-04 & Spunta & 171.5 & 44.4 & 8.8 & 14.1 & 238.8 & - \\
\hline & & SpuntaG2 & 184.9 & 78.4 & 18.8 & 18.6 & 300.7 & - \\
\hline & & $\mathrm{LSD}_{0.05}$ & NS & NS & NS & NS & NS & - \\
\hline
\end{tabular}


Table 5. Continued.

\begin{tabular}{|c|c|c|c|c|c|c|c|c|}
\hline \multirow[b]{2}{*}{ Location } & \multirow[b]{2}{*}{ Yr } & \multirow[b]{2}{*}{ Cultivar } & \multicolumn{4}{|c|}{ Yield for each size category $(\mathrm{kg})^{\mathrm{z}}$} & \multirow[b]{2}{*}{ Total yield $(\mathrm{kg})$} & \multirow[b]{2}{*}{ Total yield $\left(\mathrm{Mg} \cdot \mathrm{ha}^{-1}\right)$} \\
\hline & & & $\mathrm{L}$ & $\mathrm{M}$ & $\mathrm{S}$ & $\mathrm{U}$ & & \\
\hline & $2005-06$ & Spunta & 163.5 & 68.7 & 21.9 & 44.8 & 298.9 & 30.7 \\
\hline & & SpuntaG2 & 141.1 & 72.2 & 46.0 & 36.7 & 296.0 & 30.4 \\
\hline & 2006-07 & Spunta & 94.1 & 85.1 & 11.1 & 52.7 & 242.9 & 30.0 \\
\hline & & SpuntaG2 & 64.3 & 97.8 & 14.9 & 51.7 & 228.6 & 28.2 \\
\hline
\end{tabular}

${ }^{\mathrm{z}} \mathrm{L}=$ large $(>200 \mathrm{~g}), \mathrm{M}=$ medium $(>80 \mathrm{~g}$ and $<200 \mathrm{~g}) ; \mathrm{S}=$ small $(<80 \mathrm{~g}), \mathrm{U}=$ unmarketable (falls through sorter).

${ }^{y}$ Fisher's protected least significant difference at $\alpha=0.05$; NS $=$ not significant.

'LSDs in bold indicate significant differences between 'Spunta' and 'SpuntaG2'.

of abamectin half-way through the season to control a mite infestation in all the plots. Despite these circumstances, 'SpuntaG2' showed a statistically significant level of protection against potato tuber moth infestation for number of haulms damaged and the number of leaf mines (Table 2). At the Dendron site, early senescence prevented the evaluation of leaf infestation levels. However, 2.3\% of 'Spunta' tubers by weight were damaged by tuber moths compared with $0 \%$ of 'SpuntaG2' tubers exhibiting tuber moth damage (data not shown).

Agronomic trials. The results of the Michigan agronomic trials for 'SpuntaG2' are provided in Table 4. No significant difference was found for the agronomic performance parameters studied (total yield, marketable yield, and specific gravity) over the 3 years. The results of the South African 'SpuntaG2' agronomic trials are summarized in Table 5. While yields varied across the 5 years and six locations due to adverse weather conditions, differences in the length of the growing seasons, and the field generation of seed used for the trial, there were only five measurements where a significant difference was detected between 'Spunta' and 'SpuntaG2'. Of these differences, 'Spunta' outperformed 'SpuntaG2' in two instances: Ceres in 2003-04 (weight of medium tubers) and Dendron in 2005-06 (weight of large tubers).

Agronomic and descriptor trait comparison at Roodeplat, South Africa. 'Spunta' and 'SpuntaG2' exhibited a moderate maturity with 90 to $110 \mathrm{~d}$ from emergence to natural foliage die-back. The growth habit of both cultivars was assessed as semierect to spreading with strong growth, good to dense foliage cover, and a mature plant height of 40 to $50 \mathrm{~cm}$. Based on the 2006-07 data, tuber size distribution was not significantly different for 'Spunta' and 'SpuntaG2' under the same production practices. Both cultivars have long to very long tubers and, according to UPOV (1986), they should have a shape index (tuber length/tuber width) of 1.70 to 1.99 for long tubers and an index of greater than 2.0 for very long tubers. The average tuber shape index determined for 'Spunta' was 2.26 for medium tubers and 1.79 for large tubers. 'SpuntaG2' medium tubers had a shape index of 2.30 and large tubers had a shape index of 1.84. For both cultivars, the tubers had pale yellow skin, shallow eyes, no indentation at the point of stolon attachment, and were fairly uniform (less than $25 \%$ of the tubers displayed tuber malformation and/or knobbiness). Less than $10 \%$ of the tubers had secondary growth or growth cracks and $10 \%$ to $30 \%$ of the tubers had perceptible skin cracking or mechanical damage for 'Spunta' or 'SpuntaG2'. Internally, the two cultivars were also indistinguishable. Both cultivars had pale cream flesh with uneven color/glassiness, and no hollow heart or internal brown spot. Less than $10 \%$ of the tubers had internal bruising and $\approx 50 \%$ of the tubers had perceptible vascular discoloration. Tuber quality was also similar for 'Spunta' and 'SpuntaG2'. The average specific gravity for 'Spunta' was 1.065 with an Agtron color value of 44.5 for the resulting chips. For 'SpuntaG2', the average specific gravity was 1.07 and the average Agtron color value for the resulting chips was 45.5. The cooking quality of both cultivars was judged to be slightly mealy, fairly firm with a moderately fine texture with no tuber discoloration after cooking. Disease assessments were done for Fusarium dry rot and stem-end rot, common scab, potato late blight, potato early blight, and root knot nematode. 'Spunta' and 'SpuntaG2' had perceptible stemend rot lesions ( $25 \%-50 \%$ of the evaluated tubers), superficial cork-like scab lesions on less than $25 \%$ of the tuber surface, no potato late blight or potato early blight tuber lesions, and less than $25 \%$ of the tuber surface with visible symptoms of nematode infestation (in untreated plots). Data collected during the 2005-06 season showed no significant difference between the two cultivars for the number of inflorescences and the number of flowers per plant. 'Spunta' and 'SpuntaG2' had a high percentage of flower bud abortion resulting in a low number of flowers per plant. Pollen collected from the flowers of both cultivars was found to be sterile.

\section{Discussion}

Based on multiple years of field, storage, and agronomic trials, as well as measurement of agronomic traits, it was concluded that 'SpuntaG2' gave complete resistance to potato tuber moth infestation in the field and in storage and that it does not differ from non-transgenic 'Spunta' with respect to yield, other important agronomic properties, tuber quality, and processing traits. Furthermore, two companion articles (Quemada et al., 2010; Zarka et al., 2010) give a complete characterization of 'SpuntaG2' at the molecular level and a thorough protein safety evaluation that demonstrated that 'SpuntaG2' is safe for human consumption. Therefore, in South Africa where potato tuber moth is a serious pest of potatoes, 'SpuntaG2' could provide growers with an alternative to the variable results achieved with approved chemical insecticides. However, for 'SpuntaG2' to gain acceptance, farmer participatory trials will be necessary. To conduct farmer participatory trials with 'SpuntaG2', a general release approval is being requested from the South African government to enable farmers to plant and grow 'SpuntaG2' without confinement restrictions 
and with confidence in the environmental and food/feed safety of this new cultivar.

\section{Literature Cited}

Alexander, M.P. 1980. A versatile stain for pollen, fungi, yeast and bacteria. Biotech. Histochem. 55:13-18.

Alvarez, J.M., E. Dotseth, and P. Nolte. 2005. Potato tuberworm a threat for Idaho potatoes. 31 Mar. 2005. <http://www.info.ag.uidaho. edu/pdf/CIS/CIS1125.pdf>.

Goldson, S.L. and R.M. Emberson. 1985. The potato moth Phthorimaea operculella (Zeller): Its habits, damage potential and management. Special Publ., Agron. Soc, N.Z., Christchurch, New Zealand, p. 61-66.

International union for the protection of new varieties of plants (UPOV). 1986. Guidelines for the conduct of tests for distinctness, homogeneity and stability in potato (Solanum tuberosum L.). Document TG/23/5. UPOV, Geneva, Switzerland.

Kalazich, J.C. and R.L. Plaisted. 1991. Association between trichome characters and agronomic traits in Solanum tuberosum (L.) $\times$ S. berthaultii (Hawkes) hybrid. Amer. Potato J. 68:833-847.

Lagnaoui, A., V. Canedo, and D.S. Douches. 2000. Evaluation of Btcryllal (cry V) transgenic potatoes on two species of potato tuber moth, Phthorimaea operculella and Symmetrischema tangolias
(Lepidoptera: Gelechiidae) in Peru, p. 117-121. In: Program report 1999-2000. International Potato Center, Lima, Peru.

Mortenson, L.R., S.J. Peloquin, and R.W. Hougas. 1964. Germination of Solanum pollen on artificial media. Amer. J. Potato Res. 41:311-339.

Nel, A., M. Krause, and N. Khelawanlall. 2002. A guide for the control of plant pests. 39th ed. Natl. Dept. Agr., Directorate Agr. Productions Inputs, Pretoria, South Africa.

Quemada, H., K. Zarka, W. Pett, G. Bothma, K. Felcher, H. Mirendil, M. Koch, J. Brink, and D. Douches. 2010. Safety evaluations of the Cry1Ia1 protein found in the transgenic potato 'SpuntaG2'. J. Amer. Soc. Hort. Sci. 135:325-332.

Raman, K.V. 1980. Potato tuber moth. Tech. Info. Bul. 3. International Potato Center, Lima, Peru.

Trivedi, T.P. and D. Rajagopal. 1992. Distribution, biology, ecology and management of potato tuber moth, Phthorimaea operculella (Zeller) (Lepidopteran:Gelechiidae): A review. Trop. Pest Manage. 38:279-285.

Visser, D. 2004. The potato tuber moth, Phthorimaea operculella (Zeller), in South Africa: Potential control measures in non-refrigerated store environments. PhD Diss., Univ. of Pretoria, Pretoria, South Africa.

Zarka, K., R. Greyling, I. Gazendam, D. Olefse, K. Felcher, G. Bothma, J. Brink, H. Quemada, and D. Douches. 2010. Insertion and characterization of the crylIal gene in the potato cultivar Spunta for resistance to potato tuber moth. J. Amer. Soc. Hort. Sci. 135:317-324. 